\title{
Do Measures of Economic Reforms Complement Each Other?
}

\author{
Jonaki Sen Gupta ${ }^{1}$, Ranjanendra Narayannag'2, Rakhi Banerjee ${ }^{3 *}$ \\ ${ }^{1}$ Charuchandra College, Kolkata, India \\ ${ }^{2}$ St. Xaviers College (Autonomous), Kolkata, India \\ ${ }^{3}$ Gurudas College, Kolkata, India \\ Email: ^rakhi.banerjee77@gmail.com
}

How to cite this paper: Gupta, J.S., Narayannag, R. and Banerjee, R. (2017) Do Measures of Economic Reforms Complement Each Other? Modern Economy, 8, 333-340.

https://doi.org/10.4236/me.2017.82023

Received: January 3, 2017

Accepted: February 25, 2017

Published: February 28, 2017

Copyright (C) 2017 by authors and Scientific Research Publishing Inc. This work is licensed under the Creative Commons Attribution International License (CC BY 4.0).

http://creativecommons.org/licenses/by/4.0/

\begin{abstract}
Globalization is a package of interrelated measures including tariff liberalization and encouragement to FDI. The question to be posed is whether these measures produce similar effects reinforcing each other or they have contradictory effects. We use a three-sector general equilibrium model to show that foreign capital inflow produces unfavorable effects on unemployment and welfare while tariff liberalization produces positive effects on these variables.
\end{abstract}

\section{Keywords}

Trade Liberalization, Welfare, Capital Inflow

\section{Introduction}

Globalization is a package of interrelated measures including tariff liberalization and encouragement to Foreign Direct Investment (FDI). The question to be posed is whether these measures produce similar effects reinforcing each other or they have contradictory effects. In this paper, we use a three-sector general equilibrium model to show that foreign capital inflow produces unfavorable effects on unemployment and welfare while tariff liberalization produces positive effects on these variables.

The process of economic reforms has led to a significant change in the organization of economic activities in many emerging market economies. In the globalized world, dichotomy not only exists among sectors such as agriculture, manufacturing and services, but also exists within the sector (urban and rural). The agricultural sector is no longer a monolithic entity but is divided into two subsectors namely the traditional agriculture and the modern agriculture. The difference between the above two can be assessed in terms of nature and intensi- 
ty of inputs used, as well as consumption pattern of these commodities. According to the World Development Report (WDR) 2008, the modern agricultural sector produces processed goods primarily for exports. Some stylized facts which pertain to emergence of agricultural dualism in developing countries may be considered. WDR (2008) pointed out that fresh and processed fruits and vegetables, fish and fish products, meat, nuts, spices and floriculture accounted for $43 \%$ of agrofood exports from developing countries. The emerging pattern of trade is suggestive of the fact that the commodities produced in the traditional agricultural sector have lost their comparative advantage and have become either import competing or non-traded. Next, we consider flow of foreign capital to the modern agriculture.

Recent evidence shows that substantial amount of FDI in the World Trade Organization (WTO) regime has been flowing into the export oriented production sectors and into modern agriculture in particular. In the table, we present some stylized facts regarding sector wise FDI equity inflows in India in the agricultural sector in recent times (Table 1).

FDI into the nontraditional agricultural sector in the post WTO regime has flowed into Morocco, Chile, and India among others (WDR, 2008). This type of FDI is essentially "efficiency-seeking investment".

Radical measures aimed at reducing tariff barriers and completely abolishing non-tariff barriers have been initiated in the capital-intensive manufacturing and skilled labour intensive sectors in many developing countries. Many Sub-Saharan African countries, Latin American countries, Pakistan have made considerable progress in liberalization and deregulation policies. The formation of the World Trade Organization (WTO) has brought about significant changes in international trade. Radical measures aimed at reducing tariff barriers and completing abolition of non-tariff barriers have been initiated in small measures in developing countries. Measures of liberalization are not uniformly applied in all sectors of production; particularly the agricultural sector is exempted from such radical liberalization measures. Available statistics point out that trade liberalization may have adverse effect on employment and output. Empirical studies also point out that trade liberalization on many occasions has led to the loss of industry-specific and firm-specific human capital and has created adverse effect on balance of payments and government revenue. Although many Sub-Saharan Africans have made considerable progress in liberalization and deregulation policies, their overall performance has been poor. The average annual growth of real GDP in these countries had decreased from 2.5 percent between 1985 and 1989

Table 1. Sector-wise foreign direct investment equity inflows in India during April, 2000January, 2014.

\begin{tabular}{ccc}
\hline Name of the Sector & FDI Inflows in (Crores) & Percentage Share in Total Investment \\
\hline Agriculture Services & 8283.82 & 0.16 \\
Agriculture Machinery & 1665.45 & 0.16 \\
\hline
\end{tabular}

Source: Department of industrial policy \& promotion, ministry of commerce \& industry, govt. of India. 
to 1.9 percent between 1990 and 1997. During the 1990s, per capita income had also declined in most of Africa's less developed countries. ${ }^{1}$ Latin American Countries' experience of trade liberalization during 1990s was associated with falling employment of the formal sector. Tariff liberalization had accentuated wage inequality between skilled and unskilled labour in Latin American Countries (Wood, 1997). The non-OECD countries have been relatively slow in implementing tariff reforms. Some countries like Pakistan had initially implemented tariff reform vigorously, but later on they had increased their tariff rates. In the paper by Gochoco-Bautista [2], we found the impact of capital flows on the Philippine economy in general.

Literature on the nexus between economic reform and development is copious. Trade theorists have used general equilibrium structure to address issues like employment and welfare effects of measures of globalization. In this context the works of Brecher Alejandro [3], Brecher [4], Beladi and Marjit [5], Chaudhuri [6] [7], Marjit [8], Gochoco-Bautista [2] are worth mentioning.

To the best of our knowledge, the existing literature has not addressed the effect of economic reforms in presence of agricultural dualism. To do so is the objective of the present paper. We have departed from the existing literature on tariff rate restructuring in the following manner. The papers mentioned above have not dealt with the issue of tariff rate restructuring in presence of domestic capital being utilized in the agricultural sector and foreign capital being utilized in the modern agricultural sector. We add to the existing literature by considering the basic fact pertaining to the nature of domestic and foreign capital. In particular domestic capital and foreign capital are not perfect substitutes and they earn different rate of return in the host country. In the present paper we have endogenised the inflow of foreign capital. We have assumed that inflow of foreign capital is positively correlated with the rate of return that the foreign capital attracts. In this model we have tried to examine how different measures of liberalization complement or contradict each other.

The paper is organized as follows. In Section 2, we set up the basic model. In Section 3, we carry out the comparative static exercises pertaining to tariff rate restricting and greater inflow of FDI and concentrate on welfare consequences. Section 4 concludes the paper.

\section{The Model}

We consider 3 sector general equilibrium models with presence of urban unemployment of Harris-Todaro (HT) type. Production function obeys constant returns to scale and diminishing returns to inputs, markets are perfectly competitive and resources are fully employed. The economy is a small open economy with three sectors, and hence, prices are internationally given. All the sectors are traded. Foreign capital is specific to an export oriented modern agricultural sector $X$, while domestic capital is mobile between the import competing manufacturing sector $Y$ and export oriented traditional agricultural sector $Z$. Sector $Y$ is

${ }^{1}$ (UNCTAD, 2000) [1]. 
capital intensive relative to sector $Z$. Labour is mobile across all the sectors of production. Rates of return on foreign capital and domestic capital are different. This difference arises due to difference in the use of foreign capital and domestic capital. Specifically, these two types of capital are not substitute.

The following symbols are used to describe the equations of the model.

$X$ : Modern agricultural sector

$Y$ : Tariff protected import competing manufacturing sector

$Z$ : Export oriented traditional agricultural sector

$P_{i}^{*}$ : International price of the $i^{\text {th }}$ sector

$t$ : Ad valorem tariff

$L$ : Labour endowment

$K^{d}$ : Domestic capital endowment

$K^{f}$ : Foreign capital inflow

$L_{u}$ : Level of unemployment

$a_{i j}$ : Factor co-efficient of $i^{\text {th }}$ sector for $j^{\text {th }}$ factor

$W$ : Wage rate

$r^{d}$ : Return on domestic capital

$r^{f}$ : Return on foreign capital

$r^{*}$ : International rate of return on foreign capital

The competitive equilibrium equations are:

$$
\begin{gathered}
P_{x}^{*}=w a_{l x}+r^{f} a_{f x} \\
P_{y}^{*}(1+t)=\bar{w} a_{l y}+r^{d} a_{d y} \\
P_{Z}^{*}=w a_{l z}+r^{d} a_{d z}
\end{gathered}
$$

Endowment equations are:

$$
\begin{gathered}
K^{f}\left(r^{f}-r^{*}\right)=a_{f x} x \\
K^{d}=a_{d y} y+a_{d z} Z \\
\bar{L}=a_{l x} x+a_{l y} y+a_{l z} Z+L_{u}
\end{gathered}
$$

Finally, HT migration equilibrium conditions is given by

$$
\frac{\bar{w} a_{l y} y}{a_{l y} y+L_{u}}=w \Rightarrow \frac{\bar{w} a_{l y} y}{\bar{L}-a_{l x} x-a_{l z} z}=w \Rightarrow \bar{w} a_{l y} y+w a_{l x} x+w a_{l z} z=w \bar{L}
$$

The working of the model is as follows.

This model consists of six independent Equations (1)-(7) and six endogenous variables, $w, r^{f}, r^{d}, x, y$ and $z$ and $L_{u}$. Since the economy is a small open economy, $r^{*}$ is fixed.

The endogenous variables are determined simultaneously from Equations ((1) to (7)). From Equation (2) we determine the domestic capital interest rate. Substituting the domestic interest rate in Equation (3) we get the rural wage rate and as wage rate is determined, we will obtain the value of foreign capital interest rate $r^{f}$ from Equation (1). Again, substituting the value of $r^{f}$ in Equation (4) we can obtain the value of $x$. Once $x$ is determined, we can get $y$ and $z$ by substi- 
tuting the value of $L_{u}$ in terms of y from Equation (7) and then by solving Equations (5) and (6). Finally, we get the value of $L_{u}$ from Equation (7) by substituting the value of $y$.

\section{Comparative Static Exercises}

We here try to find the effect of tariff rate liberalization.

Taking total differentiations of the Equations ((1)-(3)) we get,

$$
\begin{gathered}
\hat{r}^{d}=\frac{t \hat{t}}{\theta_{d y}}=\beta_{1}<0 \\
\hat{w}=-\frac{t \hat{t} \theta_{d Z}}{\theta_{d y} \theta_{l z}}=\beta_{2}>0 \\
\hat{r}^{f}=-\frac{t \hat{t} \theta_{l x} \theta_{d Z}}{\theta_{f x} \theta_{l z} \theta_{d y}}=\beta_{3}<0 \\
\hat{x}=\frac{\theta_{l x} \theta_{d z} t \hat{t}\left(e_{k f}+\sigma_{1} \theta_{d z} \theta_{f x}+\sigma_{1} \theta_{l x} \theta_{d z}\right)}{\theta_{d y} \theta_{l z} \theta_{f x}}=\eta_{1}<0 \\
\hat{y}=-\frac{\eta_{4} \phi_{l z}+\eta_{8} \phi_{d z}}{|\phi|}<0 \\
\hat{z}=\frac{\phi_{d z} \eta_{8}+\left(\frac{\bar{w}-1}{w}+1\right) \eta_{4}}{|\phi|}
\end{gathered}
$$

where $|\phi|=\left|\begin{array}{cc}\phi_{d y} & \phi_{d Z} \\ \phi_{l y} & \phi_{l Z}\end{array}\right|>0$

and $\eta_{4}=\eta_{2}+\eta_{3}$, where $\eta_{2}=-\sigma_{2} \phi_{d y} \theta_{d y} \hat{r}^{d} ; \eta_{3}=\sigma_{3} \phi_{d z} \theta_{d z}\left(\hat{w}-\hat{r}^{d}\right)$

and $\eta_{8}=\eta_{5}+\eta_{6}+\eta_{7}-\phi_{l x} \hat{x}$, where $\eta_{5}=\sigma_{1} \phi_{l x} \theta_{f x}\left(\hat{w}-\hat{r}_{f}\right)$;

$$
\begin{gathered}
\eta_{6}=\left(\frac{\bar{w}-1}{w}+1\right) \sigma_{2} \phi_{l y} \theta_{d y}\left(\hat{w}-\hat{r}^{d}\right) ; \\
\eta_{7}=\sigma_{3} \theta_{d z} \phi_{l z}\left(\hat{w}-\hat{r}^{d}\right)
\end{gathered}
$$

Now, from Equation (7) we get, $L_{u}=\left(\frac{\bar{w}-1}{w}\right) a_{l y} y$

$$
\hat{L}_{u}=\left(\frac{\bar{w}-1}{w}\right)\left[\hat{a}_{l y}=\sigma_{2} \theta_{d y} \hat{r}_{d}-\frac{\eta_{4} \phi_{l z}+\eta_{8} \phi_{d z}}{|\phi|}\right]<0
$$

Proposition 1: Tariff rate liberalization in manufacturing sector causes increase in wage rate, but a fall in the rate of return of domestic capital.

Comment: Effect on wage rate and rate of return on domestic capital are obtained from Equations((8) and (9)). Since import competing manufacturing sector is relatively capital intensive relative to agricultural sector, it follows from S-S theorem, $r^{d}$ decreases and wage rate increases.

Proposition 2: Following tariff rate liberalization, one of the export sectors which uses foreign capital contracts.

Comment: Following increase in wage rate due to tariff liberalization, $r^{f}$ i.e. 
rate of return of foreign capital decreases (obtained from Equation (1)). Since foreign capital is specific to sector $X$, there is contraction of sector $X$. This has effect on production of $y$ and $z$. Given the assumption that $z$ is labour intensive relative to $y$, there is an expansion of $z$ and contraction of $y$ sector.

Proposition 3: Unemployment level in the manufacturing sector decreases following tariff rate liberalization.

Comment: As manufacturing sector i.e. sector $y$ contracts and rural sector expands, migration from agricultural sector to manufacturing sector decreases. As a result, unemployment level also decreases despite the contraction of manufacturing sector (obtained from Equation (14)).

We now concentrate on Inflow of Foreign Capital:

Consider foreign capital endowment equation as

$$
\bar{K}_{f}+K^{f}\left(r^{f}-r^{*}\right)=a_{f x} x
$$

Taking total differentiation we get,

$$
\begin{gathered}
\hat{x}=k_{f} \hat{k}_{f}>0 \\
\hat{y}=\frac{k_{f} a_{l x} \phi_{d z}}{|\phi|}>0 \\
\hat{z}=\frac{-k_{f} a_{l x} \phi_{l y}}{|\phi|}<0
\end{gathered}
$$

Now, from Equation (7) we get, $L_{u}=\left(\frac{\bar{w}-1}{w}\right) a_{l y} y$

Taking total differentiation we get,

$$
\hat{L}_{u}=\left(\frac{\bar{w}-1}{w}\right) a_{l y} \frac{\hat{y}}{\hat{k}_{f}}>0
$$

Proposition 4: Inflow of foreign capital expands modern agricultural sector and manufacturing sector while traditional agricultural sector contracts.

Comment: Since foreign capital is specific to the modern agricultural sector, Inflow of foreign capital expands sector $X$. Therefore labour is to be released from sectors $y$ and $Z$. Since $Y$ is capital intensive relative to $Z$, it follows from Rybnitzski theorem that $Z$ sector contracts and $Y$ sector expands.

Proposition 5: Inflow of foreign capital increases urban unemployment level.

Comment: Inflow of foreign capital expands manufacturing sector which paves the way for a fresh migration of labour from sector $z$ to sector $y$. Number of new migrants is greater than the number of new jobs created in the manufacturing sector and consequently the level of urban unemployment increases.

\section{Welfare Analysis}

Proposition 5: Tariff liberalization improves welfare if

$$
E_{4}>t P_{y}^{*} E_{2 u} \& \frac{w \bar{L}}{r_{d} k_{d}}>\frac{\theta_{l z}}{\theta_{d z}}
$$

Comment: We use Expenditure Function to examine effects of tariff liberali- 
zation and capital flow on welfare. Let $\mathrm{E}$ denote minimum expenditure by households to reach the equilibrium utility. Total expenditure on commodities at domestic prices must equal the value of production at domestic prices plus the tariff revenue net foreign income repatriated back.

The first condition will be satisfied if a possible improvement in welfare does not lead to significant increase in domestic consumption of $Y$. The second condition is more likely to be fulfilled in a developing country since ratio of labour income to capital income is fairly large.

Now, proposition 6 pertain to effects of capital flow on welfare.

Proposition 6: Unambiguously capital flow reduces welfare.

Comment: Since input prices remain unchanged and $Y$ sector expands, increase in foreign capital deteriorates welfare unambiguously.

\section{Conclusion}

The accent on policy making is that there are sources of discontent against globalization. The trade liberalization produces favorable effects while capital account liberalization is a chancy proposition. We have used a three-sector general disequilibrium model incorporating agricultural dualism and unemployment of Harris Todaro type for the said purpose. In the present paper, we show that inflow of foreign capital will accentuate urban unemployment and reduce welfare. On the other hand, tariff liberalization will reduce urban unemployment and increase welfare. The results of the paper are crucially dependent on factor intensity ranking and multiple cross effects present in the model. Globalization is a package of interrelated measures. However, all such measures do not reinforce each other in a very fundamental sense, that is, their effects on welfare and unemployment are contradictory. This in turn leads to discontent against globalization. In this paper, capital account liberalization has deleterious effects on welfare and unemployment. On the other hand, promotion of free trade through liberalization of tariff reduces unemployment and enhances welfare. Accordingly, the broad policy message of the paper is that policymakers of developing countries should carefully choose measures of economic reforms. In particular, the paper raises doubts regarding desirability of FDI in the developing country.

\section{References}

[1] UNCTAD (2000) The Least Developed Countries 2000 Report: Overview by the Secretary-General of UNCTAD. UNCTAD, Geneva.

[2] Gochoco-Bautista, M.S. (1997) Capital Flows and the Integration of International Financial Markets. (Unpublished Manuscript)

[3] Brecher, R.A. and Alejandro, C.F.D. (1977) Tariffs, Foreign Capital and Immiserizing Growth. Journal of International Economics, 7, 317-322. https://doi.org/10.1016/0022-1996(77)90048-4

[4] Brecher, R.A. (1983) Tariffs, Foreign Capital and National Welfare with Sector Specific Factors. Journal of International Economics, 14, 277-288. https://doi.org/10.1016/0022-1996(83)90005-3

[5] Beladi, H. and Marjit, S. (1996) An Analysis of Rural-Urban Migration and Protec- 
tion. Canadian Journal of Economics, 29, 930-940. https://doi.org/10.2307/136221

[6] Chaudhuri, S. (2006) Labour Market Reform, Welfare and Urban Unemployment in a Small Open Economy. Keio Economic Studies, 43, 1-17.

[7] Chaudhuri, S. (2007) Foreign Capital, Welfare and Urban Unemployment in the Presence of Agricultural Dualism. Japan and the World Economy, 19, 149-165. https://doi.org/10.1016/j.japwor.2005.08.001

[8] Marjit, S. (1991) Agro-Based Industry and Rural Urban Migration: A Case for an Urban Employment Subsidy. Journal of Development Economics, 35, 393-398. https://doi.org/10.1016/0304-3878(91)90057-3

Submit or recommend next manuscript to SCIRP and we will provide best service for you:

Accepting pre-submission inquiries through Email, Facebook, LinkedIn, Twitter, etc. A wide selection of journals (inclusive of 9 subjects, more than 200 journals) Providing 24-hour high-quality service User-friendly online submission system Fair and swift peer-review system Efficient typesetting and proofreading procedure Display of the result of downloads and visits, as well as the number of cited articles Maximum dissemination of your research work

Submit your manuscript at: http://papersubmission.scirp.org/

Or contact me@scirp.org 